\title{
Evaluation of Impact Hammer Mill for Limestone Crushing for Acidic Soil
}

\author{
Gizachew Tefera \\ Oromia Agricultural Research Institute, Bako Agricultural Engineering Research Center, Bako, Ethiopia
}

Email address:

gizachewtefera92@yahoo.com

\section{To cite this article:}

Gizachew Tefera. Evaluation of Impact Hammer Mill for Limestone Crushing for Acidic Soil. Engineering Science. Vol. 6, No. 2, 2021, pp. 27-32. doi: 10.11648/j.es.20210602.12

Received: May 14, 2021; Accepted: July 6, 2021; Published: July 13, 2021

\begin{abstract}
Soil acidity becomes a serious threat to crop production in most highlands of Ethiopia particularly in Western parts of Oromia. Frequent tillage, removal of crop residues and mono-cropping and heavy rainfall contributes to soil acidification by leaching of cations. Agricultural limestone raises soil $\mathrm{pH}$ and reduces solubility of potentially toxic elements such as hydrogen, aluminum $\left(\mathrm{Al}^{3+}\right)$ and manganese $(\mathrm{Mn})$ at optimum nutrient uptake by crops. To elucidate problems associated with soil acidity, a motorized agricultural limestone crusher was fabricated and evaluated. Performance of the prototype hammer mill machine, in terms of crushing capacity $(\mathrm{kg} / \mathrm{h})$, crushing efficiency $(\%)$, mean particle size (mm), fuel consumption $(\mathrm{ml} / \mathrm{kg})$ or energy consumption $(\mathrm{wh} / \mathrm{kg}$ ) was evaluated. Tests were carried out at engine speeds of $540,720,900$ $\mathrm{rpm}$, screen hole diameter of 2, 4, $6 \mathrm{~mm}$ and feed rates of $3.50,7.00,10.50 \mathrm{~kg} / \mathrm{min}$. The highest crushing capacity $630.32 \mathrm{~kg} / \mathrm{hr}$ was recorded at $900 \mathrm{rpm}$ engine speed, $6 \mathrm{~mm}$ screen hole diameter and at $10.50 \mathrm{~kg} / \mathrm{min}$ feed rate whereas the minimum 65.62 $\mathrm{kg} / \mathrm{h}$ was observed at $540 \mathrm{rpm}$ hammer mill speed, $2 \mathrm{~mm}$ screen hole diameter and at $3.50 \mathrm{~kg} / \mathrm{min}$ feed rate. The mean consumed energy ranged from 15.47 to $149.16 \mathrm{Wh} / \mathrm{kg}$ with hammer rotor speed of 540 to $900 \mathrm{rpm}$, screen hole diameter of 2 to $6 \mathrm{~mm}$ and the feeding rate of 3.5 to $10.5 \mathrm{~kg} / \mathrm{min}$. The mean particle size ranged from 0.121 to $0.448 \mathrm{~mm}$ with hammer rotor speed of 540 to $900 \mathrm{rpm}$, screen holes diameter of 2 to $6 \mathrm{~mm}$ and the feeding rate of 3.5 to $10.5 \mathrm{~kg} / \mathrm{min}$. It could be noticed that the lowest values of mean particle size were obtained at engine speed of $900 \mathrm{rpm}$, screen hole diameter of $2 \mathrm{~mm}$ and feed rate of $10.5 \mathrm{~kg} / \mathrm{min}$.
\end{abstract}

Keywords: Hammer Mill, Limestone, Particles Size and Crushing

\section{Introduction}

Agriculture contributes about $37 \%$ of the national (GDP), $73 \%$ of rural employment, and $70 \%$ of export earnings for the Ethiopian economy [5]. However, soil acidity becomes a severe crop production tricky and affects $43 \%$ of arable land in the country. Soils around Asosa and Welega in aggregate:$2.2 \%$ extremely acidic, $4 \%$ very strongly acidic, $32.8 \%$ strongly acidic, $27 \%$ moderately acidic, $3 \%$ slightly acidic and $1 \%$ neutral [1].

Major causes that speeds up soil acidification include [11, 14, 15]: Frequent tillage, Removal of crop residues, Mono-cropping, Frequent application of urea. Soil acidity restricts crop production by impairing root growth and limiting nutrient and water uptake. Crops that are grown in acidic soils have a significantly stunted growth rate and are not very responsive to fertilizers $[4,8]$. It also creates toxic soil solution that hinders the growth of roots and micro-organism activity. Lime can shift soil acidity towards neutral state and render nutrients more available to crops. Lime amounts of $2-5 \mathrm{t} / \mathrm{ha}$ are typically needed to neutralize acid soils sufficiently for crop production, depending on the type of soil and levels of acidity [12]. Ethiopian government is planned to rehabilitate 226,000 ha of agricultural land by the end of the GTP II period. To achieve this, it is planned to produce $450,000-900,000 \mathrm{t}$ of lime but, the achievement is quite low. Limestone is a geological nutrient asset that could sustain and enhance crop production is necessary for soil amendments. To improve on the effectiveness of these systems, the option of using locally available geological nutrient resources needs to be tested. Agro-minerals are physically modified by grinding and hammer mill is used because of its ability to handle a wide variety of raw materials, 
handle hard stray objects and its robustness [2]. To know the machine performances at different engine speed, feed rate and screen hole diameter, existing motorized limestone grinder should be evaluated. Therefore, this research study was intended to evaluate impact hammer mill for limestone grinding for acidic soil.

\section{Materials and Methods}

\subsection{Materials Used}

Instruments such weighing balance, oven dry, tenso-meter, impact tester, different aperture size of sieve and basic manufacturing tools and equipment were used during prototype construction, data collection and evaluation.

Particle-size distribution, crushing efficiency and capacity: Weight retained in grams for each sieve size, $(\%$ weight retained for each sieve size, and cumulative weight $\%$ passing) for each sieve size of the particle size analysis of the limestone product from the grinding test were determined.

$$
\begin{gathered}
C_{\text {eff }}=\left(\frac{M_{r}}{M_{i}}\right) \times 100 \\
\text { Crushing capacity }=\frac{\text { crushed limestone }}{\text { time taken }}\left(\frac{\mathrm{kg}}{\mathrm{h}}\right)
\end{gathered}
$$

where:

$\mathrm{C}_{\text {eff }}=$ Crushing efficiency

$\mathrm{M}_{\mathrm{i}}=$ mass of input material

$\mathrm{M}_{\mathrm{r}}=$ mass of recovered material

$$
\text { Losses }=\left(\frac{M_{b}-M_{a}}{M_{b}}\right) \times 100
$$

where:

$\mathrm{M}_{\mathrm{b}}=$ mass before grinding

$\mathrm{Ma}=$ mass after grinding

\subsection{Sieving Method and Analysis of Lime Powder}

Sample of $500 \mathrm{~g}$ was used for conducting sieve analysis and test sieves "nest" together to form a "stack" of sieves. In this work $20 \mathrm{~cm}$ diameter sieve was used and test sieve shaker provides both circular and tapping the energy and uniform mechanical motion. It is performed using a mechanical shaker for 10 minutes [7]. The test was carried out as per ASTM D44 using standard sieve analyzer "Tylers" make. After the shaking was completed, the material on each sieve was weighed. The weight of the sample of each sieve was then divided by the total weight to give a percentage retained on each sieve. The size of the average particles on each sieves were analyzed to get the cut-point or specific size range captured on the sieve. The effectiveness of agricultural lime (i.e. ground geological limestone) was accepted base on particle size to be $100 \%$ effective for particles $<0.3 \mathrm{~mm} ; 60 \%$ effective between $0.3 \mathrm{~mm}$ to $0.850 \mathrm{~mm}$ and; $10 \%$ effective for particles $>0.850 \mathrm{~mm}$ [13]. To find the percent of crushed limestone passing through each sieve, the following equation was used,

$$
\% \operatorname{Re} \text { tained }=\frac{W_{\text {sieve }}}{W_{\text {Total }}} \times 100
$$

where:

$\mathrm{W}_{\text {Sieve }}$ is the weight of crushed limestone in the sieve

$\mathrm{W}_{\text {Total }}$ is the total weight of crushed limestone

To find the cumulative percent of crushed limestone retained in each sieve, add up the total amount of crushed limestone that was retained in each sieve and the amount in the previous sieves. The cumulative percent passing of the crushed limestone was found by subtracting the percent retained from $100 \%$.

\section{$\%$ Cumulative Passing $=100 \%$ - \%Cumulative Retained}

The values were then plotted on a graph with cumulative percent passing on the $\mathrm{y}$ axis and sieve size on the $\mathrm{x}$ axis.

\subsection{Experimental Design}

The full factorial design was used for continuous grinding. For continuous grinding, an experimental plan comprising of three independent variables namely speed of mill (540, 720 and $900 \mathrm{rpm})$ and screen size having three levels (2, 4 and 6 $\mathrm{mm})$ and feed rate having three levels $(3.5,7$ and $10.5 \mathrm{~kg} / \mathrm{min})$ and dried Senkele limestone was selected purposely for evaluation. The ground product coming out of the grinding chamber was collected in a polythene bag, fastened directly under the mill to reduce the loss of fine particles. After the grinding operation, particle size distribution was determined by sieve analysis by taking a $500 \mathrm{~g}$ from each representative sample. Split plot experimental design was used for analysis of data [6].

\section{Results and Discussion}

Performance Evaluation of the Machine.

\subsection{Crushing Capacity}

The mean crushing capacity and analysis of variance were presented in (Table 1). Analysis of variances clearly indicated that the crushing capacity of hammer mill limestone grinder was significantly $(\mathrm{P}<0.05)$ affected by hammer mill speed, screen hole diameter and feed rate. The maximum crushing capacity of $630.32 \mathrm{~kg} / \mathrm{hr}$ was recorded when the hammer mill speed was $900 \mathrm{rpm}$, the screen hole diameter $6 \mathrm{~mm}$ and the feed rate $10.50 \mathrm{~kg} / \mathrm{min}$. Generally, crushing capacity increased by increasing the hammer mill speed, feed rate and screen holes diameter. [9] Showed the relationships between drum speed and machine productivity (ton $/ \mathrm{h}$ ) at different sieve diameters and feed rates. Increasing the speed increased the product with increasing the treatments of both the sieve diameter and feed in direct relationships. 
Table 1. Crushing capacity (CC in Kg/hr) of limestone crusher at various hammer mill speeds, screen hole diameter and feed rates.

\begin{tabular}{lllll}
\hline Treatments & \multicolumn{5}{l}{ Feed rates $(\mathbf{K g} / \mathbf{m i n})$} & $\mathbf{1 0 . 5 0}$ & Grand mean \\
\hline Velocity $(\mathbf{r p m})$ & Screen hole $(\mathbf{m m})$ & $\mathbf{3 . 5 0}$ & $\mathbf{7 . 0 0}$ & $180.39^{\mathrm{d}} \pm 6.25$ \\
\hline 540 & 2 & $65.62^{\mathrm{g}} 4.12$ & $134.29^{\mathrm{f}} \pm 9.37$ & $356.97^{\mathrm{b}} \pm 7.48$ \\
& 4 & $148.76^{\mathrm{e}} \pm 4.87$ & $222.62^{\mathrm{d}} \pm 2.11$ & $489.64^{\mathrm{a}} \pm 5.76$ \\
720 & 6 & $279.42^{\mathrm{c}} \pm 62.67$ & $344.55^{\mathrm{b}} \pm 54.87$ & $196.46^{\mathrm{c}} \pm 6.38$ \\
& 2 & $80.16^{\mathrm{f}} \pm 2.05$ & $163.55^{\mathrm{e}} \pm 5.72$ & $404.45^{\mathrm{c}} \pm 2.97$ \\
& 4 & $198.82^{\mathrm{c}} \pm 42.00$ & $313.87^{\mathrm{d}} \pm 12.18$ & $596.66^{\mathrm{a}} \pm 8.22$ \\
900 & 6 & $441.73^{\mathrm{c}} \pm 22.00$ & $521.21^{\mathrm{b}} \pm 12.62$ & $212.87^{\mathrm{g}} \pm 12.67$ \\
& 2 & $88.56^{\mathrm{i}} \pm 2.14$ & $168.33^{\mathrm{h}} \pm 3.30$ & $419.41^{\mathrm{d}} \pm 12.44$ \\
SEM & 4 & $259.13^{\mathrm{f}} \pm 3.97$ & $338.57^{\mathrm{e}} \pm 2.74$ & $630.32^{\mathrm{a}} \pm 2.65$ \\
LSD & 6 & $469.89^{\mathrm{c}} \pm 23.48$ & $548.12^{\mathrm{b}} \pm 14.19$ & \\
CV (\%) & 24.78 & & & 306.46 \\
\hline
\end{tabular}

SED: Standard errors of differences of means; LSD: Least significance difference; CV: Co- efficient of variation; (Two means are said to be similar or homogeneous if they are not significantly different from one another and those with different superscripts across the row are significantly different statistically at $(\mathrm{p}<0.05)$. Values were means \pm standard deviation.

\subsection{Crushing Efficiency}

The mean percent crushing efficiency of the limestone crusher prototype and analysis of variance are given in (Table 2). Analysis of variance revealed that hammer mill speeds and screen hole diameter had significant $(\mathrm{p}=0.01)$ effect on crushing efficiency. As can be seen from (Table 2), increasing engine speed resulted in increased crushing efficiency. At higher hammer mill speed the energy imparted to the limestone was high hence causing higher crushing. The
Results obtained showed that crushing efficiency increases with increasing screen hole diameter and hammer mill speed and [3] reported similar findings.

The highest crushing efficiency $99.61 \%$ was recorded at $900 \mathrm{rpm}$ engine speed, $6 \mathrm{~mm}$ screen hole diameter and at $10.50 \mathrm{~kg} / \mathrm{min}$ feed rate; whereas the lowest crushing efficiency $95.48 \%$ was recorded at $540 \mathrm{rpm}$ engine speed, 2 $\mathrm{mm}$ screen hole diameter and at $3.50 \mathrm{~kg} / \mathrm{min}$ feed rate as can be seen from Table 2 .

Table 2. Crushing efficiency (CE, \%) of limestone crusher at various hammer mill speeds, screen hole diameter and feed rates.

\begin{tabular}{|c|c|c|c|c|c|}
\hline \multicolumn{2}{|l|}{ Treatments } & \multicolumn{3}{|c|}{ Feed rate $(\mathrm{kg} / \mathrm{min})$} & \multirow[b]{2}{*}{ Grand mean } \\
\hline velocity (rpm) & screen hole $(\mathbf{m m})$ & 3.50 & 7.00 & 10.50 & \\
\hline \multirow[t]{3}{*}{540} & 2 & $95.48^{\mathrm{a}} \pm 0.05$ & $96.06^{\mathrm{b}} \pm 0.06$ & $96.48^{\mathrm{c}} \pm 0.08$ & \\
\hline & 4 & $97.73^{\mathrm{a}} \pm 0.05$ & $98.02^{\mathrm{b}} \pm 0.05$ & $98.34^{\mathrm{c}} \pm 0.10$ & \\
\hline & 6 & $98.67^{\mathrm{a}} \pm 0.05$ & $98.95^{\mathrm{b}} \pm 0.05$ & $99.17^{\mathrm{c}} \pm 0.07$ & \\
\hline \multirow[t]{3}{*}{720} & 2 & $96.64^{\mathrm{a}} \pm 0.05$ & $97.10^{\mathrm{b}} \pm 0.10$ & $97.80^{\mathrm{c}} \pm 0.05$ & \\
\hline & 4 & $98.22^{\mathrm{a}} \pm 0.05$ & $98.39^{\mathrm{b}} \pm 0.05$ & $98.70^{c} \pm 0.049$ & \\
\hline & 6 & $98.89^{\mathrm{a}} \pm 0.05$ & $99.05^{\mathrm{b}} \pm 0.05$ & $99.27^{\mathrm{c}} \pm 0.05$ & \\
\hline \multirow[t]{3}{*}{900} & 2 & $97.97^{\mathrm{a}} \pm 0.16$ & $98.56^{\mathrm{b}} \pm 0.21$ & $98.86^{\mathrm{c}} \pm 0.16$ & \\
\hline & 4 & $99.05^{\mathrm{a}} \pm 0.17$ & $99.27^{\mathrm{b}} \pm 0.17$ & $99.50^{c} \pm 0.16$ & \\
\hline & 6 & $99.36^{\mathrm{a}} \pm 0.16$ & $99.48^{\mathrm{b}} \pm 0.16$ & $99.61^{\mathrm{c}} \pm 0.16$ & 98.33 \\
\hline SEM & 0.13 & & & & \\
\hline LSD & 0.07 & & & & \\
\hline CV (\%) & 0.14 & & & & \\
\hline
\end{tabular}

SED: Standard errors of differences of means; LSD: Least significance difference; CV: Co- efficient of variation; (Two means are said to be similar or homogeneous if they are not significantly different from one another and those with different superscripts across the row are significantly different statistically at $(\mathrm{p}<0.05)$. Values were means \pm standard deviation.

\subsection{Consumed Energy}

The relationship between consumed energy (CE) and hammer rotor speed $(\mathrm{V})$ at different feeding rates $(\mathrm{F})$ and screen holes diameters $(\mathrm{S})$ were illustrated in (Table 3). The obtained data showed that the consumed energy decreased with increasing feeding rate, screen holes diameter and hammer mill speed. The mean consumed energy ranged from
15.47 to $149.16 \mathrm{Wh} / \mathrm{kg}$ with hammer rotor speed of 540 to $900 \mathrm{rpm}$, screen holes diameter of 2 to $6 \mathrm{~mm}$ and the feeding rate of 3.5 to $10.5 \mathrm{~kg} / \mathrm{min}$. It could be noticed that the lowest values of consumed energy were obtained at engine speed $(\mathrm{V})$ $900 \mathrm{rpm}$, screen hole diameter (S) $6 \mathrm{~mm}$ and feed rate (Fr) of $10.5 \mathrm{~kg} / \mathrm{min}$, however the highest values of consumed energy were obtained at engine speed (V) $540 \mathrm{rpm}$, sreen hole diameter (S) $2 \mathrm{~mm}$ and feed rate (F) $3.5 \mathrm{~kg} / \mathrm{min}$ and Dabbour 
et al. (2015) reports justify similar findings.

Table 3. Energy consumption $(\mathrm{Wh} / \mathrm{kg}$ ) of limestone crusher at various hammer mill speeds, screen hole diameter and feed rates.

\begin{tabular}{|c|c|c|c|c|c|}
\hline \multicolumn{2}{|l|}{ Treatments } & \multicolumn{3}{|c|}{ Feed rate $(\mathrm{Kg} / \mathrm{min})$} & \multirow[b]{2}{*}{ Grand mean } \\
\hline Velocity (rpm) & Screen hole (mm) & 3.50 & 7.00 & 10.50 & \\
\hline \multirow[t]{3}{*}{540} & 2 & $149.16^{\mathrm{a}} \pm 9.31$ & $72.95^{\mathrm{b}} \pm 5.04$ & $54.11^{\mathrm{c}} \pm 1.87$ & \\
\hline & 4 & $65.61^{\mathrm{a}} \pm 2.17$ & $43.80^{\mathrm{b}} \pm 0.42$ & $27.33^{\mathrm{c}} \pm 0.57$ & \\
\hline & 6 & $36.48^{\mathrm{a}} \pm 7.10$ & $28.96^{\mathrm{b}} \pm 4.16$ & $19.92^{\mathrm{c}} \pm 0.23$ & \\
\hline \multirow[t]{3}{*}{720} & 2 & $121.71^{\mathrm{a}} \pm 3.06$ & $59.69^{\mathrm{b}} \pm 2.05$ & $49.68^{\mathrm{c}} \pm 1.58$ & \\
\hline & 4 & $51.03^{\mathrm{a}} \pm 9.44$ & $31.11^{\mathrm{b}} \pm 1.22$ & $24.11^{\mathrm{b}} \pm 0.18$ & \\
\hline & 6 & $22.13^{\mathrm{a}} \pm 1.18$ & $18.72^{\mathrm{a}} \pm 0.45$ & $16.34^{\mathrm{a}} \pm 0.23$ & \\
\hline \multirow[t]{3}{*}{900} & 2 & $110.16^{\mathrm{a}} \pm 2.62$ & $57.94^{\mathrm{b}} \pm 1.12$ & $45.96^{\mathrm{c}} \pm 2.69$ & \\
\hline & 4 & $37.64^{\mathrm{a}} \pm 0.58$ & $28.80^{\mathrm{b}} \pm 0.23$ & $23.27^{\mathrm{c}} \pm 0.69$ & \\
\hline & 6 & $20.80^{\mathrm{a}} \pm 1.08$ & $17.80^{\mathrm{a}} \pm 0.47$ & $15.47^{\mathrm{a}} \pm 0.06$ & 46.32 \\
\hline SEM & 4.178 & & & & \\
\hline LSD & 2.28 & & & & \\
\hline CV (\%) & 9.02 & & & & \\
\hline
\end{tabular}

SED: Standard errors of differences of means; LSD: Least significance difference; CV: Co- efficient of variation; (Two means are said to be similar or homogeneous if they are not significantly different from one another) Values were means \pm standard deviation and those with different superscripts across the row are significantly different statistically at $(\mathrm{p}<0.05)$.

\subsection{Mean Particle Size}

The relationship between mean particle size of the limestone particle after ground and hammer rotor speed (V) at different feeding rates (F) and screen holes diameter (S) were illustrated in (Table 4). The obtained data showed that mean particle size increased with increasing screen holes diameter and feeding rate and decreased with increasing hammer speed. The mean particle size ranged from 0.121 to $0.448 \mathrm{~mm}$ with hammer rotor speed of 540 to $900 \mathrm{rpm}$, screen holes diameter of 2 to $6 \mathrm{~mm}$ and the feeding rate of 3.5 to $10.5 \mathrm{~kg} / \mathrm{min}$. It could be noticed that the lowest values of mean particle size were obtained at engine speed $(\mathrm{V})$ of $900 \mathrm{rpm}$, screen hole diameter (S) of $2 \mathrm{~mm}$ and feed rate (Fr) of $10.5 \mathrm{~kg} / \mathrm{min}$.

Table 4. Mean particle size ( $\mathrm{mm}$ ) of crushed limestone at various hammer mill speeds, screen hole diameter and feed rates.

\begin{tabular}{lllll}
\hline Treatments & \multicolumn{5}{l}{ Feed rate $(\mathbf{K g} / \mathbf{m i n})$} & \\
\hline V (rpm) & Scr. diameter & $\mathbf{3 . 5 0}$ & $\mathbf{7 . 0 0}$ & $\mathbf{1 0 . 5 0}$ \\
\hline 540 & 2 & $0.28^{\mathrm{a}} \pm 0.01$ & $0.28^{\mathrm{b}} \pm 0.03$ & $0.28^{\mathrm{a}} \pm 0.01$ \\
& 4 & $0.34^{\mathrm{a}} \pm 0.00$ & $0.35^{\mathrm{b}} \pm 0.00$ & $0.35^{\mathrm{a}} \pm 0.01$ \\
& 6 & $0.44^{\mathrm{c}} \pm 0.09$ & $0.44^{\mathrm{b}} \pm 0.02$ & $0.45^{\mathrm{a}} \pm 0.04$ \\
720 & 2 & $0.18^{\mathrm{b}} \pm 0.01$ & $0.18^{\mathrm{a}} \pm 0.01$ & $0.19^{\mathrm{a}} \pm 1.58$ \\
& 4 & $0.30^{\mathrm{ab}} \pm 0.02$ & $0.30^{\mathrm{b}} \pm 0.02$ & $0.30^{\mathrm{a}} \pm 0.02$ \\
& 6 & $0.33^{\mathrm{c}} \pm 0.04$ & $0.33^{\mathrm{b}} \pm 0.05$ & $0.34^{\mathrm{a}} \pm 0.05$ \\
900 & 2 & $0.12^{\mathrm{a}} \pm 0.01$ & $0.12^{\mathrm{a}} \pm 0.0$ & $0.12^{\mathrm{a}} \pm 0.00$ \\
& 4 & $0.16^{\mathrm{c}} \pm 0.05$ & $0.1637^{\mathrm{b}} \pm 0.00$ & $0.17^{\mathrm{b}} \pm 0.00$ \\
SEM & 6 & $0.20^{\mathrm{a}} \pm 0.03$ & $0.20^{\mathrm{a}} \pm 0.00$ & $0.21^{\mathrm{a}} \pm 0.01$ \\
LSD & 0.02 & & & 0.26 \\
CV $(\%)$ & 0.32 & & & \\
\hline
\end{tabular}

SED: Standard errors of differences of means; LSD: Least significance difference; CV: Co- efficient of variation; (Two means are said to be similar or homogeneous if they are not significantly different from one another and those with different superscripts across the row are significantly different statistically at $(\mathrm{p}<0.05)$. Values were means \pm standard deviation.

\subsection{Fuel Consumption}

The analysis of variance, on fuel consumption of the crushing machine, revealed that hammer mill speed, screen hole diameter and hopper feed rate had highly significant $(\mathrm{P}=0.01)$ effects on the fuel consumption. In general, fuel consumption increases with in increasing of engine speeds and decrease with increasing screen hole diameter and increase with increasing of feed rates. The mean fuel consumption ranged from 8.62 to $47.99 \mathrm{ml} / \mathrm{kg}$ with hammer rotor speed of 540 to $900 \mathrm{rpm}$, screen holes diameter of 2 to 6 $\mathrm{mm}$ and the feeding rate of 3.5 to $10.5 \mathrm{~kg} / \mathrm{min}$. It could be noticed that the lowest values of fuel consumption were obtained at engine speed (V) $540 \mathrm{rpm}$, screen hole diameter (S) $6 \mathrm{~mm}$ and feed rate (Fr) of $3.5 \mathrm{~kg} / \mathrm{min}$, however the highest values of fuel consumption were obtained at engine speed (V) $900 \mathrm{rpm}$, screen hole diameter (S) $2 \mathrm{~mm}$ and feed rate (F) $10.5 \mathrm{~kg} / \mathrm{min}$. (Table 5) indicating that fuel consumption would be increased with increasing rate of work and feed though it appears to decrease with increasing screen 
hole diameter manifesting the effect of screen hole diameter on fuel consumption during crushing.

Table 5. Fuel consumption of engine (FC, $\mathrm{ml} / \mathrm{kg})$ for hammer mill prototype when operated at different speeds, screen hole diameter and feed rates.

\begin{tabular}{lllll}
\hline Treatments & \multicolumn{3}{l}{ Feed rate $\mathbf{~ K g / m i n})$} \\
\hline Velocity $(\mathbf{r p m})$ & Screen hole $(\mathbf{m m})$ & $\mathbf{3 . 5 0}$ & $\mathbf{7 . 0 0}$ & $\mathbf{1 0 . 5 0}$ \\
\hline 540 & 2 & $14.66^{\mathrm{c}} \pm 1.07$ & $16.98^{\mathrm{b}} \pm 0.55$ & $18.34^{\mathrm{a}} \pm 0.75$ \\
& 4 & $10.54^{\mathrm{ef}^{\mathrm{f}}} \pm 0.85$ & $12.67^{\mathrm{d}} \pm 0.94$ & $15.26^{\mathrm{c}} \pm 0.85$ \\
& 6 & $8.62^{\mathrm{g}} \pm 0.51$ & $9.72^{\mathrm{f}} \pm 0.52$ & $11.40^{\mathrm{e}} \pm 0.70$ \\
720 & 2 & $29.00^{\mathrm{e}} \pm 0.63$ & $34.33^{\mathrm{c}} \pm 0.76$ & $39.33^{\mathrm{a}} \pm 0.25$ \\
& 4 & $20.98^{\mathrm{h}} \pm 0.54$ & $27.45^{\mathrm{f}} \pm 1.03$ & $35.54^{\mathrm{b}} \pm 0.94$ \\
& 6 & $20.58^{\mathrm{h}} \pm 1.35$ & $25.85^{\mathrm{g}} \pm 1.73$ & $31.37^{\mathrm{d}} \pm 0.55$ \\
900 & 2 & $35.81^{\mathrm{d}} \pm 0.41$ & $39.70^{\mathrm{c}} \pm 0.43$ & $48.00^{\mathrm{a}} \pm 0.68$ \\
& 4 & $28.82^{\mathrm{g}} \pm 0.45$ & $34.92^{\mathrm{e}} \pm 0.21$ & $42.24^{\mathrm{b}} \pm 0.50$ \\
SEM & 6 & $27.97^{\mathrm{g}} \pm 0.23$ & $33.01^{\mathrm{f}} \pm 0.31$ & $38.99^{\mathrm{c}} \pm 0.11$ \\
LSD & 0.85 & & & 26.37 \\
CV $(\%)$ & 0.50 & & & \\
\hline
\end{tabular}

SED: Standard errors of differences of means; LSD: Least significance difference; CV: Co- efficient of variation; (Two means are said to be similar or homogeneous if they are not significantly different from one another and those with different superscripts across the row are significantly different statistically at $(p<0.05)$. Values were means \pm standard deviation.

\subsection{Sieve Particle Size Analysis}

Sample of $500 \mathrm{~g}$ was used for conducting sieve analysis and test sieves "nest" together to form a "stack" of sieves. In this work $20 \mathrm{~cm}$ diameter sieve was used and performed using a mechanical shaker within 10 minutes and carried out as per ASTM D44 using standard sieve analyzer "Tylers" make. After the shaking was completed, the material on each sieve was weighed and divided by the total weight to give a percentage retained on each sieve. The size of the average particles on each sieve then was analyzed to get the cut-point or specific size range captured on the sieve.

To find the cumulative percent weight of crushed limestone retained in each sieve, add up the total weight of crushed limestone that was retained in each sieve and the amount in the previous sieves. The cumulative percent passing of the weight of crushed limestone was found by subtracting the percent retained from $100 \%$. The values are then plotted on a graph with cumulative percent passing on the $\mathrm{y}$ axis and sieve size on the $\mathrm{x}$ axis.

Table 6. Cumulative percent passing through sieve and \% retained for engine speed of $900 \mathrm{rpm}$, screen hole diameter of $6 \mathrm{~mm}$ and feed rate of $10.5 \mathrm{~kg} / \mathrm{mi}$ (at maximum efficiency and crushing capacity)

\begin{tabular}{|c|c|c|c|c|c|c|}
\hline Sieve № & Mesh size (mm) & WR & $\% R$ & CW & $\%$ CUM & \%Fine \\
\hline 8 & 2 & 0 & 0 & 0 & 0 & 100 \\
\hline 16 & 1.18 & 2.71 & 0.542 & 2.71 & 0.542 & 99.46 \\
\hline 30 & 0.6 & 17.68 & 3.54 & 20.39 & 4.08 & 95.92 \\
\hline 50 & 0.3 & 39.27 & 7.85 & 59.66 & 11.93 & 88.07 \\
\hline 100 & 0.15 & 189.15 & 37.83 & 248.81 & 49.76 & 50.24 \\
\hline 200 & 0.075 & 228.35 & 45.67 & 477.16 & 95.43 & 4.57 \\
\hline
\end{tabular}

Coefficient of Uniformity (CU) (ASTM D2487) $=\mathrm{D}_{60} / \mathrm{D}_{10}=0.19 / 0.0825=2.3, \mathrm{D}_{30}=0.12$

Coefficient of curvature $(\mathrm{Cc})(\mathrm{ASTM} D 2487)=\left(\mathrm{D}_{30}\right)^{2} /\left(\mathrm{D}_{10} \times \mathrm{D}_{60}\right)=(0.12)^{2} /(0.0825 \times 0.19)=0.92$

D60 $=$ Diameter corresponding to $60 \%$ finer in the grain size distribution. D30=Diameter corresponding to $30 \%$ finer in the grain size distribution. D10=Diameter corresponding to $10 \%$ finer in the grain size distribution [13].

\section{Conclusion and Recommendations}

\subsection{Conclusion}

In light of the aim and objectives stated, the tested results showed that the machine gave a satisfactory performance in output, energy and fuel consumption. The machine also has room for easy maintenance activities such as replacement of screen, hammers and cleaning of the bottom casing. The utilization of the machine is not limited to only limestone and it can be used in poultry and fish food processing and iodized salt processing and can be milled provided they are dried. Lastly, the fabricated machine was constructed with locally sourced material and has fewer components; hence, the purchase price of the machine can be kept low.

\subsection{Recommendations}

Based on the finding obtained, the performance of impact hammer mill machine appear to be most efficient at $900 \mathrm{rpm}$ engine speed, $6 \mathrm{~mm}$ screen hole diameter and $10.50 \mathrm{~kg} / \mathrm{min}$ feed rate. 


\section{Acknowledgements}

My deepest gratitude and acknowledgement go to Oromia Agricultural Research Institute (OARI) and Bako Agricultural Engineering Research Center for the provision of funds to cover costs associated with research work. I greatly indebted to the technicians of BAERC workshop who shared with me their wisdom, skill, experience and helped me during collection of data and assisted me with all the necessary inputs in the production of the prototype from the very beginning up to end.

\section{References}

[1] Abdenna, Deressa, Negassa, Chewaka and Tilahun Geleto. 2007. Inventory of Soil Acidity Status in Crop Lands of Central and Western Ethiopia. "Utilization of diversity in land use systems: Sustainable and organic approaches to meet needs" October 9-11, 2007.

[2] Ajaka, Oyedele. 2014. Design Fabrication and Performance Testing of a Laboratory Size Hammer Mill. International Journal of Engineering and Advanced Technology Studies. Vol. 2 .

[3] Babale, M., 1988. Fabrication of an egusi shelling machine. Agric. Engineering Determent.

[4] Desta, Beyene. 1988. Soil Science Research in Ethiopia: A proceedings of the first soil science research review workshop, 11-14 February 1986, IAR, Addis Ababa, Ethiopia.

[5] FAO. 2019. The future of livestock in Ethiopia Opportunities and challenges in the face of uncertainty. Food and Agriculture Organization of the United Nations, Rome, 2019.

[6] Gomez A. K., and Gomez A. A. 1984. Statistical procedures for agricultural research. John Wiley and Sons, New York, p. 357-379.
[7] GTM-20. 2015. Test method for the grain-size analysis of granular materials. Department of Transportation, Revision 5, State of New York.

[8] Mesfin Abebe. 2007. Nature and Management of Acid Soils in Ethiopia. Haramaya University College of Agriculture. pp. 18.

[9] Refaay, and El_Sayed A. S. 2016. Developing a hammer mill for grinding seashells. Journal of Soil Science and Agricultural Engineering. Mansoura University, Egypt. Vol. 7 pp: 801-808.

[10] Stone Y., Ahern CR., Blunden B. 1998. Acid sulfate soils manual. (Acid Sulfate Soils Management Advisory Committee; Wollongbar, NSW).

[11] Tamene Lulseged; Amede Tilahun; Kihara J; Tibebe Degefi; Schulz S. (eds.). 2017. A review of soil fertility management and crop response to fertilizer application in Ethiopia: towards development of site- and context specific fertilizer recommendation. CIAT Publication No. 443. International Center for Tropical Agriculture (CIAT), Addis Ababa, Ethiopia. $86 \mathrm{p}$.

[12] Tegbaru Bellete. 2015. $2^{\text {nd }}$ IPI; MoANR, ATA and Hawassa university joint symposium. Hawassa Uninersity, Ethiopia.

[13] USDA. 2018. National SMETE Digital Library Program, administered by the University of Nebraska, Plant and Soil Sciences eLibrary.

[14] Wassie Haile and Shiferaw Boke. 2009. Mitigation of soil acidity and fertility decline challenges for sustainable livelihood improvement: research findings from southern region of Ethiopia and its policy implications.

[15] Wassie Haile and Shiferaw Boke. 2011. On-Farm Verification of Lime and NPK Fertilizers Effects on the Tuber Yield of Irish Potato (Solanum Tuberosum) on Some Acidic Soils of Southern Ethiopia. Journal of the Dry lands, 4 (1): 283-288. 